\title{
PENGARUH SUHU RUANG DAN LAMA PENYIMPANAN TERHADAP VIGOR BENIH DAN KECAMBAH SORGUM VARIETAS SUPER-2
}

\author{
Diana Pangastuti ${ }^{1}$, Kukuh Setiawan ${ }^{2}$, Eko Pramono ${ }^{2}$, Nyimas Sa'diyah ${ }^{2}$ \\ ${ }^{1}$ Mahasiswa Jurusan Agroteknologi, Fakultas Pertanian, Universitas Lampung \\ ${ }^{2}$ Dosen Jurusan Agroteknologi, Fakultas Pertanian, Universitas Lampung \\ Jl Sumantri Brojonegoro 1, Bandar Lampung 35145, Indonesia \\ Email: diana.pangastuti1@gmail.com
}

\begin{abstract}
ABSTRAK
Tanaman sorgum merupakan salah satu sumber bahan pangan alternatif. Sorgum dapat dijadikan sebagai salah satu tanaman pangan alternatif di masa depan yang mempunyai banyak manfaat untuk memenuhi kebutuhan pangan Indonesia. Salah satu cara pengembangan sorgum yaitu penyediaan benih bermutu dan memiliki vigor benih dan kecambah yang tinggi pasca penyimpanan. Kemunduran benih selama penyimpanan berbanding lurus dengan lamanya penyimpanan itu sendiri. Laju kemunduran benih selama penyimpanan dipengaruhi oleh suhu ruang simpannya. Tujuan penelitian ini yaitu mengetahui pengaruh suhu ruang simpan dan lama penyimpanan terhadap vigor benih dan kecambah sorgum varietas Super-2. Penelitiaan ini dilaksanakan di Laboratorium Benih dan Pemuliaan Tanaman, Fakultas Pertanian, Universitas Lampung yang berlangsung dari Februari 2017 sampai dengan Februari 2018. Penelitian ini disusun dengan strip plot lengkap (SPL) 2x4 dengan 3 ulangan. Petak utama yaitu suhu ruang simpan (T) yang terdiri dari 2 taraf yaitu suhu ruang $\operatorname{simpan} \pm 18^{\circ} \mathrm{C}$ (T1) dan suhu ruang simpan $\pm 26^{\circ} \mathrm{C}(\mathrm{T} 2)$. Anak petak yaitu lama penyimpanan (P) yang terdiri dari 4 taraf yaitu 0 bulan (P1), 4 bulan (P2), 8 bulan (P3), dan 12 bulan (P4). Suhu ruang simpan tidak berpengaruh nyata pada vigor benih dan kecambah sorgum varietas Super-2. Lama penyimpanan berpengaruh nyata pada vigor benih dan kecambah sorgum varietas Super-2. Vigor benih sudah nyata menurun setelah lama penyimpanan 4 bulan yang ditunjukkan oleh variabel kecambah normal total dan kecepatan perkecambahannya, sedangkan vigor kecambah signifikan menurun setelah lama penyimpanan 8 bulan yang ditunjukkan oleh variabel kecambah normal kuat dan bobot kering kecambah normal. Efek interaksi suhu ruang simpan dan lama penyimpanan tidak berpengaruh pada vigor benih dan kecambah sorgum varietas Super-2.
\end{abstract}

Kata Kunci : Simpan, sorgum, suhu, vigor

\section{PENDAHULUAN}

Tanaman sorgum merupakan salah satu sumber bahan pangan alternatif. Menurut Direktorat Serealia (2013), tanaman sorgum merupakan salah satu tanaman sumber pangan yang sangat berpotensi dikembangkan di Indonesia dan dapat menjadi salah satu solusi dari permasalahan krisis pangan. Sorgum mempunyai daya adaptasi tinggi dan dapat tumbuh dihampir semua jenis tanah di Indonesia, dengan demikian sorgum dapat dijadikan sebagai salah satu tanaman pangan alternatif di masa depan yang mempunyai banyak manfaat untuk memenuhi kebutuhan pangan Indonesia.

Sorgum memiliki kandungan nutrisi yang lebih tinggi dibandingkan dengan beras. Menurut Widowati (2012), kandungan nutrisi sorgum jika dibandingkan 
dengan beras lebih tinggi sorgum, sorgum mengandung protein $8-12 \%$ setara dengan terigu atau lebih tinggi dibandingkan dengan beras 6-10\%, dan kandungan lemaknya 2-6\% lebih tinggi dibandingkan dengan beras 0,5-1,5\%. Kandungan nutrisi sorgum yang lebih tinggi dibandingkan dengan beras sehingga mampu menopang kebutuhan nutrisi yang dibutuhkan. Salah satu varietas unggul sorgum adalah varietas Super-2, varietas ini memiliki produktivitas 6,3 ton/ha, kandungan karbohidratnya $75,6 \%$, proteinnya $9,2 \%$, dan lemaknya 3,1\%.

Menurut Sukarman dan Raharjo (2000), suhu ruang simpan berperan dalam mempertahankan vigor benih selama penyimpanan, yang dipengaruhi oleh kadar air benih, dan kelembaban nisbi ruangan. Pada suhu rendah, respirasi berjalan lambat dibanding suhu tinggi. Dalam kondisi tersebut, vigor benih lebih tahan disimpan. Untuk menghambat kemunduran benih khususnya vigor benih dan kecambah maka benih harus disimpan dengan metode tertentu. Penyimpanan benih adalah usaha mempertahankan viabilitas benih tetap tinggi, sampai ditanam kembali atau untuk tujuan pelestarian benih dari suatu jenis tanaman (Sutopo, 2002).

Menurut Sutopo (2014), vigor benih adalah kemampuan benih untuk tumbuh normal pada keadaan lingkungan yang suboptimal. Lot benih yang mempunyai vigor tinggi akan mampu bertahan pada kondisi yang ekstrim dan proses penuaan lambat dibandingkan dengan lot benih yang mempunyai vigor rendah. Lot benih yang mempunyai vigor tinggi akan tetap memiliki daya berkecambah tinggi, sedangkan lot benih yang mempunyai vigor rendah daya berkecambahnya akan berkurang (ISTA, 2009).

Vigor kecambah adalah vigor yang ditunjukan oleh bentuk fisik kecambah normal. Kecambah yang bervigor tinggi menunjukkan fisik komponen kecambah yg lebih unggul daripada yg kecambah kurang vigor (less vigor). Vigor benih dan kecambah sangat penting dalam bidang budidaya pertanian yaitu untuk memperkirakan kedalaman lubang tanam pada saat pertanaman. Selain itu juga vigor benih dan kecambah yang tinggi sangat berpengaruh terhadap hasil produksi tanaman yang dibudidayakan. Dengan begitu pada penelitian ini benih sorgum disimpan pada suhu ruang simpan $\pm 18^{\circ} \mathrm{C}$ dan $\pm 26^{\circ} \mathrm{C}$ serta menurunkan kadar air awal hingga 8\% agar lama simpannya mencapai 12 bulan dengan daya berkecambah yang masih tinggi dan dapat digunakan untuk pertanaman di periode tanam berikutnya.

Dengan demikian, berdasarkan uraian diatas, tujuan penelitian adalah untuk mengetahui vigor benih dan kecambah pada sorgum varietas Super-2 setelah disimpan pada suhu ruang simpan $\pm 18^{\circ} \mathrm{C}$ dan $\pm 26^{\circ} \mathrm{C}$. Mengetahui pada lama simpan berapa bulan vigor benih dan kecambah menurun secara signifikan selama penyimpanan $0,4,8$, dan 12 bulan pada sorgum varietas Super-2. Mengetahui vigor benih dan kecambah benih sorgum varietas Super-2 menurun secara signifikan untuk benih yang disimpan pada suhu ruang simpan $\pm 18^{\circ} \mathrm{C}$ dan $\pm 26^{\circ} \mathrm{C}$ selama penyimpanan $0,4,8$, dan 12 bulan. 


\section{BAHAN DAN METODE}

Penelitian ini dilakukan di Laboratorium Benih dan Pemuliaan Tanaman Fakultas Pertanian Universitas Lampung. Waktu penelitian dimulai pada Februari 2017 sampai dengan Februari 2018. Bahan-bahan yang digunakan dalam penelitian ini adalah benih sorgum varietas Super-2 pada taraf lama simpan 0, 4, 8, dan 12 bulan, kadar air 8\%, kertas merang, kertas CD, dan larutan aquades. Alat-alat yang digunakan pada penelitian ini adalah Germinator Tipe IPB 73 2A/2B, (Seed counter) Tipe Seedburo, Oven Tipe UMB 500, Moisture tester, timbangan elektrik Tipe Scount pro, nampan, plastik, plastik klip, label, straples, penggaris, dan alat tulis.

Perlakuan disusun dengan strip plot lengkap (SPL) 2x4) dengan 3 ulangan. Petak utama yaitu suhu ruang simpan $(\mathrm{T})$ yang terdiri dari 2 taraf yaitu suhu ruang simpan $18 \pm 1,58^{\circ} \mathrm{C}(\mathrm{T} 1)$ dan suhu ruang simpan $26 \pm 1,08^{\circ} \mathrm{C}(\mathrm{T} 2)$. Anak petak yaitu lama penyimpanan (P) yang terdiri dari 4 taraf yaitu 0 bulan (P1), 4 bulan (P2), 8 bulan (P3), dan 12 bulan (P4). Asumsi untuk analisis ragam, yaitu homogenitas ragam antar perlakuan dengan Uji Bartllet, dan sifat kemenambahan data dengan Uji Tukey. Pengaruh antarperlakuan dengan analisis ragam dari pembandingan nilai tengah perlakuan menggunakan uji Beda Nyata Jujur (BNJ) pada taraf nyata $5 \%$.

Pelaksanaan dalam penelitian ini meliputi persiapan benih sorgum, pengemasan benih sorgum, penyimpanan benih sorgum, dan pengukuran variabel pengamatan. Pengamatan vigor benih meliputi variabel kecambah normal total, kecepatan perkecambahan, kecambah abnormal, benih mati. Pengamatan vigor kecambah meliputi kecambah normal kuat, kecambah normal lemah, panjang tajuk kecambah normal, panjang akar primer kecambah normal, dan bobot kering kecambah normal.

Vigor benih dievaluasi dengan uji perkecambahan. Uji perkecambahan ini dilakukan dengan media kertas merang dengan metode uji kertas digulung (UKD). Sebanyak 25 butir benih disusun diatas 2 lembar kertas merang lembab yang diberi alas selembar plastik kemudian digulung (ISTA, 2009). Benih yang dikecambahkan dalam gulungan diletakkan pada germinator tipe IPB $732 \mathrm{~A} / 2 \mathrm{~B}$ dengan suhu 28,17 $\pm 1,79^{\circ} \mathrm{C}$. Kecambah normal yang muncul dari benih tersebut diamati mulai hari ke-2 sampai hari ke-5 setelah perkecambahan. Kecambah yang sudah dinyatakan normal dalam pengamatan pada hari ke-2 dihitung dengan mengambil dari media pengecambahan tersebut. Kecambah yang belum dinyatakan normal atau belum berkecambah dibiarkan dalam media perkecambahan untuk diamati pada hari berikutnya sampai dengan hari ke-5 setelah perkecambahan. Benih mati dan kecambah abnormal dievaluasi pada hari ke5 setelah perkecambahan.

Vigor kecambah dievaluasi dengan uji perkecambahan. Pada uji perkecambahan menggunakan metode uji kertas digulung (UKD) dengan media kertas CD. Sebanyak 25 butir benih sorgum varietas Super-2 yang dikecambahkan pada 2 kertas CD lembab yang diberi alas selembar plastik kemudian digulung(ISTA, 2009). Benih yang sudah dikecambahkan dalam gulungan diletakkan pada 
germinator tipe IPB 73 2A/2B dengan suhu 28,17 \pm $1,79^{\circ} \mathrm{C}$. Kemudian diamati mulai hari ke-4 setelah perkecambahan. Hasil uji perkecambahan tersebut digunakan untuk pengamatan persentase kecambah normal kuat, persentase kecambah normal lemah, panjang tajuk kecambah normal, panjang akar primer kecambah normal, dan bobot kering kecambah normal.

\section{HASIL DAN PEMBAHASAN}

Suhu ruang simpan tidak berpengaruh terhadap 9 variabel yang diamati, sedangkan lama penyimpanan berpengaruh pada variabel kecambah normal total, kecepatan perkecambahan, benih mati, kecambah normal kuat, kecambah normal lemah, panjang tajuk kecambah normal dan bobot kering kecambah normal. Begitu juga interaksi keduanya tidak berpengaruh terhadap variabel yang diamati (Tabel 1).

Suhu ruang simpan $\mathrm{AC} 18^{\circ} \mathrm{C}$ dan suhu kamar $26^{\circ} \mathrm{C}$, tidak berpengaruh kecambah normal total, kecepatan perkecambahan, benih mati, kecambah abnormal, kecambah normal kuat, kecambah normal lemah, panjang tajuk kecambah normal, panjang akar primer kecambah normal dan bobot kering kecambah normal pada benih sorgum varietas Super-2 (Tabel2).

Berdasarkan hal tersebut diduga bahwa benih yang disimpan pada suhu ruang simpan $\mathrm{AC} 18^{\circ} \mathrm{C}$ dan suhu kamar $26^{\circ} \mathrm{C}$ masih toleran karena disimpan dengan kadar air awal yang rendah yaitu 8\% maka tidak berpengaruh terhadap vigor benih dan kecambahnya. Hal ini sejalan dengan penelitian Hakim (2017) menunjukkan bahwa genotipe GH-6 yang disimpan pada suhu ruang simpan $26^{\circ} \mathrm{C}$ dengan kadar air $10 \%$ masih memiliki daya berkecambah yang tinggi yaitu $75 \%$ setelah disimpan selama 9 bulan. Hasil penelitian tersebut tidak jauh berbeda dengan penelitian Timotiwu (2017) yang membuktikan bahwa benih yang disimpan pada suhu ruang simpan $18^{\circ} \mathrm{C}$ dengan kadar air $10 \%$ setelah disimpan selama 10 bulan memiliki daya berkecambah $78 \%$.

Menurut Tatipata (2008) bahwa pada saat protein, lemak, karbohidrat, phosphor, kalsium, dan magnesium menurun maka akan terjadi peningkatan

Tabel 1. Nilai F-hit ringkasan analisis ragam pengaruh suhu ruang simpan (T), lama penyimpanan (P), dan interaksi suhu dan lama penyimpanan (TxP) pada vigor benih dan kecambah

\begin{tabular}{|c|c|c|c|c|}
\hline \multirow{2}{*}{ No. } & \multirow{2}{*}{ Variabel Pengamatan } & \multicolumn{3}{|c|}{ Perlakuan } \\
\hline & & $\mathrm{T}$ & $\mathrm{P}$ & $\mathrm{T} \times \mathrm{P}$ \\
\hline 1. & Kecambah Normal Total $(\%)$ & $4,54 \mathrm{tn}$ & $18,95^{*}$ & $0.37 \mathrm{tn}$ \\
\hline 2. & Kecepatan Perkecambahan (\%/hari) & $1,57 \mathrm{tn}$ & $25,46^{*}$ & $0,22 \mathrm{tn}$ \\
\hline 3. & Benih Mati (\%) & $3,98 \mathrm{tn}$ & $13,52 *$ & $0,83 \mathrm{tn}$ \\
\hline 4. & Kecambah Abnormal (\%) & $0,67 \mathrm{tn}$ & $1,11 \mathrm{tn}$ & $0,56 \mathrm{tn}$ \\
\hline 5. & Kecambah Normal Kuat (\%) & $1,98 \mathrm{tn}$ & $80,50 *$ & $0,83 \mathrm{tn}$ \\
\hline 6. & Kecambah Normal Lemah (\%) & $0,00 \mathrm{tn}$ & $19,99 *$ & $0,02 \mathrm{tn}$ \\
\hline 7. & Panjang Tajuk Kecambah Normal $(\mathrm{cm})$ & $0,02 \mathrm{tn}$ & $20,18^{*}$ & $4,10 \mathrm{tn}$ \\
\hline 8. & Panjang Akar Primer Kecambah Normal (cm) & 0,19 tn & $1,99 \mathrm{tn}$ & $0,32 \mathrm{tn}$ \\
\hline 9. & Bobot Kering Kecambah Normal (mg) & $0,35 \mathrm{tn}$ & $4,56 *$ & $0,63 \mathrm{tn}$ \\
\hline
\end{tabular}

Keterangan : $*$ = berbeda nyata pada á $: 0,05 ; \mathrm{tn}=$ tidak berbeda nyata pada á : 0,05 
Tabel 2. Pengaruh suhu ruang terhadap vigor benih dan kecambah sorgum varietas Super-2

\begin{tabular}{clccc}
\hline \multirow{2}{*}{ No. } & \multirow{2}{*}{ Variabel Pengamatan } & \multicolumn{2}{c}{ Suhu } & \multirow{2}{*}{ BNJ 5\% } \\
\cline { 3 - 4 } & \multirow{2}{*}{ Kecambah Normal Total (\%) } & $\pm 18^{0} \mathrm{C}$ & $\pm 26^{0} \mathrm{C}$ & \\
2. & Kecepatan Perkecambahan(\%/hari) & $75,0^{\mathrm{a}}$ & $71,67^{\mathrm{a}}$ & 14,81 \\
3. & Kecambah Abnormal (\%) & $27,97^{\mathrm{a}}$ & $25,46^{\mathrm{a}}$ & 6,26 \\
4. & Benih Mati (\%) & $2,17^{\mathrm{a}}$ & $1,50^{\mathrm{a}}$ & 17,83 \\
5. & Kecambah Normal Kuat (\%) & $22,83^{\mathrm{a}}$ & $29,17^{\mathrm{a}}$ & 12,86 \\
6. & Kecambah Normal Lemah (\%) & $71,0^{\mathrm{a}}$ & $66,67^{\mathrm{a}}$ & 11,23 \\
7. & Panjang Tajuk Kecambah Normal (cm) & $0,46^{\mathrm{a}}$ & $0,47^{\mathrm{a}}$ & 0,66 \\
8. & Panjang Akar Primer Kecambah Normal (cm) & $10,0^{\mathrm{a}}$ & $10,10^{\mathrm{a}}$ & 2,34 \\
9. & Bobot Kering Kecambah Normal (mg) & $11,29^{\mathrm{a}}$ & $11,08^{\mathrm{a}}$ & 2,41 \\
\hline
\end{tabular}

Keterangan : Baris yang diikuti oleh huruf yang sama tidak berbeda menurut uji BNJ 5\%.

transfer asam amino, gula, dan asam lemak kotiledon sehingga daya berkecambahnya mulai menurun. Benih dengan kandungan protein yang rendah akan lebih cepat mengalami kerusakan benih. Benih sorgum varietas

Super-2 memiliki embrio yang kecil dengan kandungan protein yang rendah, sehingga lebih cepat mengalami kerusakan pada embrionya pada saat dikeringkan kadar airnya hingga 8\%. Lama penyimpanan benih sorgum mempengaruhi semua variabel yang diamati kecuali kecambah abnormal dan panjang akar primer kecambah normal (Tabel 3). Hasil penelitian menunjukkan lama penyimpanan 12 bulan dengan kadar air 8\% mempengaruhi vigor benih dan vigor kecambah sorgum varietas Super-2. Variabel pengamatan vigor benih meliputi kecambah normal total, kecepatan perkecambahan, dan benih mati. Pada benih sorgum varietas Super-2 pada variabel kecambah normal total sebelum penyimpanan persentase perkecambah meliputi 97,33\%, setelah dilakukan penyimpanan 4 bulan benih sorgum mengalami penurunan secara signifikan menjadi $71,33 \%$. Persentase perkecambahan yang semakin menurun setelah penyimpanan 4 bulan. Hal ini sejalan dengan persentase kecepatan perkecambahan yang menunjukkan penurunan setelah dilakukan penyimpanan 4 bulan. Persentase kecepatan perkecambahan sebelum penyimpanan yaitu $40,17 \%$ sedangkan setelah peyimpanan 4 bulan mengalami penurunan persentase kecepatan perkecambahan menjadi 25,43\%. Proses perkecambahan yang terhambat menyebabkan kecambah abnormal dan benih mati yang semakin tinggi.

Menurut Fitriningtyas (2008) menyatakan tingginya kerusakan benih menunjukkan semakin rendahnya vigor benih. Rendahnya vigor benih ditunjukkan dengan menurunnya persentase kecepatan perkecambahan. Hal ini sejalan dengan pernyataan Tuwu et al. (2012) bahwa pada umumnya vigor benih mengalami penurunan atau kemunduran kronologis setelah melewati periode simpan tertentu. Hasil penelitian ini menunjukkan lama penyimpanan 12 bulan 
Tabel 3. Pengaruh lama penyimpanan terhadap vigor benih dan vigor kecambah sorgum varietas Super-2

\begin{tabular}{|c|c|c|c|c|c|c|}
\hline \multirow{2}{*}{ No. } & \multirow{2}{*}{ Variabel Pengamatan } & \multicolumn{4}{|c|}{ Lama simpan (bulan) } & \multirow{2}{*}{ BNJ 5\% } \\
\hline & & 0 & 4 & 8 & 12 & \\
\hline 1. & Kecambah Normal Total (\%) & $97,33^{\mathrm{a}}$ & $71,33^{\mathrm{b}}$ & $65,33^{\mathrm{b}}$ & $59,33^{\mathrm{b}}$ & 20,09 \\
\hline 2. & Kecepatan Perkecambahan(\%/hari) & $40,17^{\mathrm{a}}$ & $25,43^{b}$ & $22,92^{\mathrm{b}}$ & $18,33^{\mathrm{b}}$ & 8,50 \\
\hline 3. & Benih Mati (\%) & $2,00^{\mathrm{a}}$ & $32,67^{\mathrm{ab}}$ & $31,33^{\mathrm{ab}}$ & $38,0^{\mathrm{b}}$ & 24,19 \\
\hline 4. & Kecambah Abnormal (\%) & $0,67^{\mathrm{a}}$ & $0,67^{\mathrm{a}}$ & $3,33^{\mathrm{a}}$ & $2,67^{\mathrm{a}}$ & 3,87 \\
\hline 5. & Kecambah Normal Kuat (\%) & $94,67^{\mathrm{a}}$ & $65,33^{\mathrm{ab}}$ & $65,33^{\mathrm{ab}}$ & $50,0^{\mathrm{b}}$ & 15,24 \\
\hline 6. & Kecambah Normal Lemah (\%) & $0,40^{\mathrm{ab}}$ & $0,35^{\mathrm{ab}}$ & $0.00^{\mathrm{a}}$ & $1,11^{\mathrm{b}}$ & 0,89 \\
\hline 7. & Panjang Tajuk Kecambah Normal (cm) & $9,87^{\mathrm{ab}}$ & $10,73^{\mathrm{ab}}$ & $11,98^{\mathrm{b}}$ & $7,62^{\mathrm{a}}$ & 3,17 \\
\hline 8. & $\begin{array}{l}\text { Panjang Akar Primer Kecambah } \\
\text { Normal }(\mathrm{cm})\end{array}$ & $10,33^{\mathrm{a}}$ & $12,67^{\mathrm{a}}$ & $10,92^{\mathrm{a}}$ & $10,82^{\mathrm{a}}$ & 3,27 \\
\hline 9. & Bobot Kering Kecambah Normal (mg) & $9,60^{\mathrm{a}}$ & $8,80^{\mathrm{ab}}$ & $8,10^{\mathrm{ab}}$ & $7,80^{\mathrm{b}}$ & 0,21 \\
\hline
\end{tabular}

Keterangan : Baris yang diikuti oleh huruf yang sama tidak berbeda menurut uji BNJ 5\%.

dengan kadar air 8\% mempengaruhi vigor kecambah yang ditunjukkan oleh variabel kecambah normal kuat dan bobot kering kecambah normal. Berdasarkan hal tersebut persentase kecambah normal kuat sebelum dilakukan penyimpanan yaitu 94,67\% sedangkan setelah dilakukan penyimpanan mengalami penurunan persentase menjadi 50\%. Persentase panjang tajuk kecambah normal menunjukkan hasil yang relatifnaik turun. Persentase sebelum dilakukan penyimpanan yaitu 9,87\% kemudian setelah dilakukan penyimpanan 8 bulan persentasenya menjadi 11,98\% dan menurun saat setelah dilakukan penyimpanan 12 bulan yaitu 7,62\%. Penurunan tersebut dikarenakan terjadinya kerusakan benih pada saat dilakukannya penyimpanan yang berdampak pada kemampuan benih untuk berkecambah normal. Berdasarkan pengamatan yang telah dilakukan panjang tajuk kecambah normal yang tinggi justru memiliki bobot kering kecambah normal yang rendah dikarenakan kuantitas kecambah yang dihasilkan semakin ringan. Hal tersebut sesuai dengan pernyataan Justice dan Bass (2002) menjelaskan bahwa bobot kering kecambah normal salah satu indikator vigor kecambah, tingginya nilai bobot kering kecambah normal menunjukkan tingginya vigor kecambah. Sejalan dengan hasil yang ditunjukkan oleh persentase bobot kering kecambah normal dimana semakin lama dilakukan penyimpanan bobot kering kecambah normal juga semakin rendah persentasenya.

Berdasarkan hasil penelitian maka lebih disarankan untuk menyimpan benih sorgum suhu ruang simpan $26^{\circ} \mathrm{C}$ dengan kadar air $8 \%$ karena suhu ruang simpan tidak berpengaruh terhadap vigor benih dan kecambah sehingga tidak perlu mengeluarkan biaya tambahan untuk menggunakan pendingin ruangan (AC).

\section{KESIMPULAN}

Berdasarkan hasil penelitian dan pembahasan, kesimpulan yang dapat diperoleh yaitu penyimpanan benih pada ruang simpan $18^{\circ} \mathrm{C}$ atau $26^{\circ} \mathrm{C}$ tidak menyebabkan perbedaan vigor benih dan kecambah 
sorgum varietas Super-2. Vigor benih dan kecambah sorgum varietas Super-2 signifikan menurun setelah lama penyimpanan 4 bulan yang ditunjukkan oleh variabel kecambah normal total dan kecepatan perkecambahannya, sedangkan vigor kecambah signifikan menurun setelah lama penyimpanan 8 bulan yang ditunjukkan oleh variabel kecambah normal kuat dan bobot kering kecambah normal. Pengaruh interaksi suhu ruang dan lama penyimpanan tidak nyata pada vigor benih dan kecambah sorgum varietas Super-2.

\section{DAFTAR PUSTAKA}

Direktorat Serealia. 2013. Kebijakan Direktorat Jenderal Tanaman Pangan dalam Pengembangan Komoditas Serealia untuk Mendukung Pertanian Bioindustri. Makalah Disampaikan pada Seminar Nasional Serealia. Maros Sulawesi Selatan. $213 \mathrm{hlm}$.

Fitriningtyas. 2008. Laporan Akhir Tahun RPTP Proses Pascapanen pada Tanaman Jagung dan Sorgum. Balai Tanaman Serealia. Maros, Sulawesi Selatan.

Hakim, F. A. 2017. Pengaruh Genotipe Pada Produksi dan Mutu Benih Sorgum (Sorghum bicolor [L.] Moench) Pasca Simpan 3 dan 9 Bulan. Skripsi. Universitas Lampung. Lampung. 58 hlm.

[ISTA] International Seed Testing Association, 2009. Handbook on seedling evaluation. Third edition with amendmends 2009.

Justice, O.L. dan L.N. Bass. 2002. Prinsip Praktek Penyimpanan Benih. Diterjemahkan oleh Rennie Roesli. PT. Raja Grafindo
Persada.Jakarta

Sutopo, L. 2002. Teknologi Benih. Raja Grafindo Persada. Jakarta. 238 hlm.

Sutopo, L. 2014. Teknologi Benih (Edisi Revisi Fakultas Pertanian UNIBRAW). Jakarta: PT Raja Grafindo Persada. 197 hlm.

Sukarman dan Raharjo. 2000. Perbaikan mutu benih aneka tanaman melalui cara panen dan penanganan benih. Jurnal Litbang Pertanian (8):57-62.

Tatipata, A. 2008. Pengaruh Kadar Air Awal, kemasan dan lama simpan terhadap protein membrane dalam mitokondria benih kedelai. Bul. Agron. (36) (1) 7-16 (2008).

Timotiwu, P.B., Eko, P., Agustiansyah and Ni Wayan, S.A. 2017. Effect of Storage Periods on Physical Quality and Seed Vigor of Four Varieties of Sorghum. Sorghum bicolor [L.] Moench). Research in Agriculture Journal 2(2): 30-40.

Tuwu. 2012. Pengaruh wadah, Ruang dan Periode Simpan terhadap Viabilitas Benih Kilemo (Litsea cubeba Persoon L.). Balai Penelitian Teknologi Perbenihan Tanaman Hutan. Bogor.

Widowati. 2012. Karakteristik Mutu Gizi dan Diversifikasi Pangan Berbasis Sorgum (Sorghum vulgare). Balai Besar penelitian dan Pengembangan Pasca Panen Pertanian. Bogor. 158 hlm. 